\title{
Aplikasi sistem pakar diagnosis penyakit ispa berbasis speech recognition menggunakan metode naive bayes classifier
}

\author{
Mariam Marlina $^{1}$, Wiwin Saputra ${ }^{2}$, Bohati Mulyadi ${ }^{3}$, Bismi Hayati $^{4}$, Jaroji $^{5}$ \\ 1,2,3,4,5 Politeknik Negeri Bengkalis \\ Jl. Bathin Alam Sungai Alam - Bengkalis - Riau, telp/fax. (+62766) 24566 \\ ${ }^{1}$ mariammarlina@gmail.com, ${ }^{2}$ wiwinsaputra50@gmail.com, \\ ${ }^{3}$ bohatiti15b@student.polbeng.ac.id, ${ }^{4}$ bismi.rpl16a@student.polbeng.ac.id, \\ 5jaroji@polbeng.ac.id
}

\begin{abstract}
Abstrak
ISPA (Infeksi Saluran Pernafasan Akut) adalah suatu penyakit gangguan saluran pernapasan yang dapat menimbulkan berbagai spektrum penyakit mulai dari penyakit tanpa gejala, infeksi ringan sampai penyakit yang parah dan mematikan akibat faktor lingkungan. Kurangnya pengetahuan masyarakat mengenai gejala dan cara penanganan penyakit ISPA merupakan salah satu faktor penyebab tingginya angka kematian akibat ISPA. Peran sistem pakar yang disediakan dalam bentuk aplikasi sangat diperlukan untuk membantu seseorang dalam melakukan diagnosa penyakit ISPA secara mudah dan cepat. Dengan berusaha mengadopsi pengetahuan manusia ke komputer, sistem pakar mampu menyelesaikan permasalahan seperti yang dilakukan oleh seorang pakar. Oleh Karena itu, Aplikasi Sistem Pakar Diagnosis Penyakit ISPA Berbasis Speech Recognition Menggunakan Metode Naive Bayes Classifier dapat digunakan untuk mendiagnosis penyakit ISPA terhadap seseorang berdasarkan konversi hasil deteksi suara pengguna. Dengan aplikasi ini pengguna seakan berkonsultasi kepada seorang dokter/pakar yang menangani penyakit ISPA. Aplikasi dibangun berbasis android dengan menggunakan bahasa pemrograman Java dan database MySQL.
\end{abstract}

Kata kunci : Sistem pakar, speech recognition, ISPA, metode naïve bayes classifier, Android.

\begin{abstract}
ISPA (Acute Respiratory Tract Infection) is a respiratory disorder disease that can lead to a wide spectrum of diseases ranging from asymptomatic disease, mild infection to severe and deadly disease due to environmental factors. So if someone complains of respiratory disorders not necessarily just have regular respiratory problems because it could be the person has ARI disease. The role of expert systems provided in the form of an application is needed to help a person in the diagnosis of ARI disease easily and quickly. By trying to adopt human knowledge into a computer, an expert system is capable of solving problems like that of an expert. Therefore, the Application of Expert System Diagnosis of ISPA Disease Based Speech Recognition Using the Naive Bayes Classifier Method can be used to diagnose ARI disease against a person based on the conversion of the user's voice detection result. With this application the user seemed to consult a doctor / expert who treats ARI disease. The application is built based on android using Java programming language and MySQL database.
\end{abstract}

Keywords: Expert system, speech recognition, Acute Respiratory Infection, naïve bayes classifier method, Android. 


\section{Pendahuluan}

Perkembangan teknologi informasi dewasa ini sangat pesat. Hampir semua bidang terpengaruh oleh perkembangan ini, salah satunya adalah bidang kesehatan. Hal ini mendorong para ahli untuk semakin mengembangkan komputer agar dapat membantu kerja manusia, salah satunya adalah sistem pakar. Sistem pakar adalah program berbasis pengetahuan yang menyediakan solusi-solusi dengan kualitas pakar untuk masalah yang spesifik. Sistem pakar merupakan sistem yang berusaha mengadopsi pengetahuan manusia ke komputer, agar komputer dapat menyelesaikan masalah seperti yang biasa dilakukan oleh para ahli, atau dengan kata lain sistem yang didesain dan diimplementasikan dengan bantuan bahasa pemrograman tertentu untuk dapat menyelesaikan masalah seperti yang dilakukan oleh para ahli. Selain itu, sistem pakar juga dapat memberikan hasil yang lebih konsisten daripada pakar. Sistem pakar dapat melakukan pengambilan kesimpulan lebih cepat daripada pakar (Ahmad, dkk, 2015).

Infeksi Saluran Pernapasan Akut (ISPA) adalah penyakit saluran pernapasan atas atau bawah, biasanya menular, yang dapat menimbulkan berbagai spektrum penyakit yang berkisar dari penyakit tanpa gejala atau infeksi ringan sampai penyakit yang parah dan mematikan, tergantung pada patogen penyebabnya, faktor lingkungan, dan faktor pejamu. ISPA adalah penyebab utama morbiditas dan mortalitas penyakit menular di dunia. Hampir empat juta orang meninggal akibat ISPA setiap tahun, 98\%-nya disebabkan oleh infeksi saluran pernapasan bawah. Tingkat mortalitas sangat tinggi pada bayi, anak-anak, dan orang lanjut usia, terutama di negara-negara dengan pendapatan per kapita rendah dan menengah (WHO, 2007).

Menurut Kementerian Kesehatan Republik Indonesia (2016) ISPA merupakan penyakit yang bisa menyerang semua kalangan tanpa melihat umur dan wilayah. Di Indonesia, penyakit ISPA menjadi salah satu penyakit yang berbahaya diantaranya adalah pneumonia. Sampai dengan tahun 2014, angka cakupan penemuan pneumonia balita tidak mengalami perkembangan berarti, yaitu berkisar antara 20\%-30\%. Pada tahun 2015 terjadi peningkatan menjadi $63,45 \%$. Angka kematian akibat pneumonia pada balita sebesar $0,16 \%$ mengalami peningkatan dibandingkan dengan tahun 2014 yang sebesar 0,08\% .

Kurangnya pengetahuan masyarakat mengenai gejala dan cara penanganan penyakit ISPA merupakan salah satu faktor penyebab tingginya angka kematian akibat ISPA (Hendra, 2016). Selama ini, sistem diagnosa penyakit harus dilakukan dengan melibatkan dokter secara langsung dengan melakukan pencatatan dan analisa secara manual. Hal ini tidak menutup kemungkinan dapat menimbulkan kesalahan atau berbeda diagnosis. Untuk mengatasinya diperlukan suatu alat bantu berupa sistem pakar yang dapat mendiagnosis penyakit ISPA (Deni, 2013).

Berdasarkan latar belakang diatas, maka diperlukan sebuah sistem pakar untuk melakukan diagnosis penyakit ISPA dan memberikan hasil yang konsisten. Sebelumnya sudah ada yang melakukan penelitian tentang sistem pakar penyakit ispa ini diantaranya adalah Hendra (2016) membahas tentang Sistem pakar diagnosis penyakit infeksi saluran pernapasan akut pada anak menggunakan metode Naive Bayes Classifier berbasis web. Sistem pakar ini bertujuan agar dapat membantu masyarakat untuk mendiagnosis penyakit ISPA pada anak berdasarkan gejala-gejala yang diderita. Kemudian menurut Deni (2013) membahas tentang Sistem pakar diagnosa ISPA berbasis web dengan metode Forward Chaining . Sistem pakar ini bertujuan untuk membantu dan mempermudah pengguna dalam mengidentifikasi/diagnosa ISPA melalui gejala yang dipilih serta mendapatkan hasil diagnosanya.

Oleh karena itu, peneliti ingin membuat sebuah sistem pakar diagnosa penyakit ISPA berbasis android yang lebih interaktif menggunakan Speech Recognition dengan metode Naive Bayes Classifier yang dapat membantu masyarakat dalam mendiagnosis penyakit ISPA berdasarkan gejala-gejala yang dihadapi layaknya berkonsultasi dengan dokter. Sistem pakar ini mampu mendiagnosis penyakit ISPA sekaligus memberikan solusi yang dilengkapi dengan google maps yang mampu menunjukkan lokasi rumah sakit terdekat yang disarankan. Sistem pakar ini dibuat dengan memanfaatkan library Google Speech dan Google Maps dengan 
didukung bahasa pemrograman Java, dan Android Studio sebagai Integrated Development Environment (IDE) pengembang perangkat lunak dan MySQL sebagai database.

\section{Tinjuan Pustaka}

a. ISPA

ISPA didefinisikan sebagai penyakit saluran pernapasan akut yang disebabkan oleh agen infeksius yang ditularkan dari manusia ke manusia. Timbulnya gejala biasanya cepat, yaitu dalam waktu beberapa jam sampai beberapa hari. Gejalanya meliputi demam, batuk, dan sering juga nyeri tenggorok, coryza (pilek), sesak napas, mengi, atau kesulitan bernapas. Contoh patogen yang menyebabkan ISPA yang dimasukkan dalam pedoman ini adalah rhinovirus, respiratory syncytial virus, paraininfluenzaenza virus, severe acute respiratory syndromeassociated coronavirus (SARS-CoV), dan virus Influenza (WHO, 2007).

\section{b. Speech Recognition}

Speech recognition disebut juga sebagai speech-to-text adalah kemampuan mengkonversi suara kebentuk text dengan mencocokkan suara dengan kosakata yang telah disediakan. sistem pengenalan terdiri dari lima blok yaitu fitur ekstraksi, modeling akustik, pengucapan pemodelan, decoder. Proses pengenalan suara dimulai dengan speaker menciptakan ucapan yang terdiri dari gelombang suara. Gelombang suara kemudian ditangkap oleh mikrofon dan diubah menjadi sinyal listrik. Sinyal-sinyal listrik kemudian dikonversi ke dalam bentuk digital untuk membuat mereka dimengerti oleh pidato-sistem. Sinyal suara kemudian diubah menjadi urutan diskrit vektor fitur, yang diasumsikan hanya berisi informasi yang relevan tentang diberikan ucapan yang penting untuk pengenalan yang benar (Saini dan Kaur, 2013).

\section{c. Metode Nä̈ve Bayes Clasifier}

Menurut Hendra (2016), Nä̈ve Bayes Classifier merupakan pengklasifikasi probabilitas sederhana berdasarkan pada Teorema Bayes dikombinasikan dengan "Nä̈ve" yang berarti setiap atribut/variable bersifat bebas (independent). Nä̈ve Bayes Classifier dapat dilatih dengan efisien dalam pembelajaran terawasi (supervised learning). Keuntungan dari klasifikasi adalah bahwa ia hanya membutuhkan sejumlah kecil data pelatihan untuk memperkirakan parameter (sarana dan varians dari variabel) yang diperlukan untuk klasifikasi. Karena variabel independen diasumsikan, hanya variasi dari variabel untuk masing-masing kelas harus ditentukan, bukan seluruh matriks kovarians.

Pada saat klasifikasi, pendekatan bayes akan menghasilkan label kategori yang paling tinggi probabilitasnya ( $\left.V_{M A P}\right)$ dengan masukan atribut $a_{1} a_{2} a_{3} \ldots a_{n}$

Teorema Bayes menyatakan :

$$
V_{\text {MAP }}=\operatorname{argmax}_{v_{i} \in v} P\left(v_{j} \mid a_{1} a_{2} a_{3} \ldots a_{n}\right)
$$

$$
P(B \mid A)=\frac{P(A \| B) P(B)}{P(A)}
$$

Menggunakan Teorema Bayes ini, persamaan (1) dapat ditulis sebagai berikut :

$$
V_{M A P}=\operatorname{argmax}_{v_{j} \in v} \frac{P\left(a_{1} a_{2} a_{g m} a_{n} \| v_{j}\right) P\left(v_{j}\right)}{P\left(a_{1} a_{n} a_{g} \omega a_{n}\right)}
$$

Nilai $P\left(a_{1} a_{2} a_{3} \ldots a_{n}\right)$ konstan untuk semua $v_{j}$ sehingga persamaan (3) dapat ditulis menjadi :

$$
V_{\text {MAP }}=\operatorname{argmax}_{v_{j} \in v} P\left(a_{1} a_{2} a_{3} \ldots a_{n} \mid v_{j}\right) P\left(v_{j}\right)
$$

Karena nilai $P\left(a_{1} a_{2} a_{3} \ldots a_{n} \mid v_{j}\right)$ sulit untuk dihitung, maka diasumsikan bahwa setiap atribut pada kategori tidak mempunyai keterkaitan sehingga :

$P\left(a_{i} \mid v_{j}\right)$ didapat dari rumus :

$$
V_{\text {MAP }}=\operatorname{argmax}_{v_{j} \in v} P\left(v_{j}\right) \pi_{i} P\left(a_{i} \mid v_{j}\right)
$$

$$
P\left(a_{i} \mid v_{j}\right)=\frac{n_{c}+m, p}{n+m}
$$


Dimana :

$n_{c}=$ jumlah record pada data learning yang $\mathrm{v}=v_{j}$ dan $\mathrm{a}=a_{i}$

$\mathrm{p}=1 /$ banyaknya jenis penyakit

$\mathrm{m}=$ jumlah gejala

$\mathrm{n}=$ jumlah record pada data learning yang $\mathrm{v}=n_{c} /$ tiap penyakit.

Tahap perhitungan Nä̈ve Bayes Classifier

Perhitungan Nä̈ve Bayes Classifier dilakukan dengan langkah-langkah sebagai berikut :

1. Menentukan nilai $n_{c}$ untuk setiap class

2. Menghitung nilai $P\left(a_{i} \mid v_{j}\right)$ dan $P\left(v_{j}\right)$.

3. Menghitung nilai $P\left(v_{j}\right) \times P\left(a_{i} \mid v_{j}\right)$ untuk setiap v.

4. Menentukan hasil klasifikasi yaitu v yang memiliki nilai perkalian terbesar.

\section{Metode Penelitian}

Dalam penelitian ini digunakan tahapan-tahapan yang dilakukan untuk memastikan upaya penelitian dan perancangan aplikasi akan mencapai hasil yang maksimal.

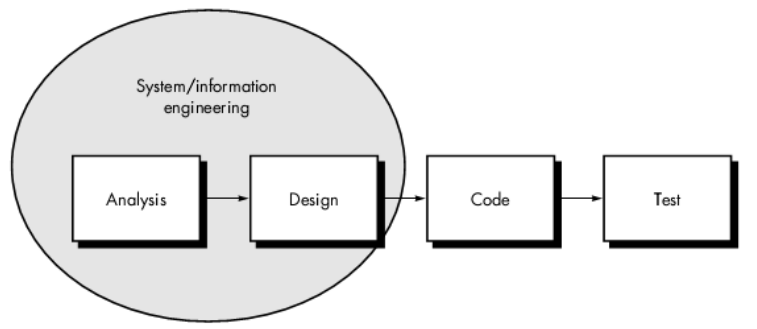

Gambar: 2.1 Model Waterfall

(Sumber: Pressman, 2011)

1. Analysis

Pada tahap ini merupakan tahapan analisa permasalahan. Analisa ini meliputi analisa sistem yang sedang berjalan dan sistem yang diusulkan. Peneliti mengumpulkan data-data berupa jenis penyakit, gejala penyakit, dan Rule nä̈ve bayes classifier dan data pendukung lainnya. Berikut merupakan jenis dan gejala penyakit beserta rule berdasarkan konsultasi dengan dokter spesialis penyakit dalam.

Tabel 1. Jenis Penyakit

\begin{tabular}{|l|l|l|}
\hline No & $\begin{array}{l}\text { Kode } \\
\text { Penyakit }\end{array}$ & Jenis Penyakit \\
\hline 1 & P1 & Rhinosinusitis / Sinusistis \\
\hline 2 & P2 & $\begin{array}{l}\text { Tonsilitis, Faringitis, Laringitis } \\
\text { (Radang Tenggorokan) }\end{array}$ \\
\hline 3 & P3 & Epiglotis \\
\hline 4 & P4 & Bronkitis \\
\hline 5 & P5 & Bronkiolitis \\
\hline 6 & P6 & Pneumonia \\
\hline 7 & P7 & Pleuritis \\
\hline 8 & P8 & Commond Cold \\
\hline 9 & P9 & ILI ( Influenza Like Illness) \\
\hline
\end{tabular}


Tabel 2. Gejala Penyakit

\begin{tabular}{|l|l|l|}
\hline No & $\begin{array}{l}\text { Kode } \\
\text { Gejala }\end{array}$ & Gejala \\
\hline 1 & G1 & Demam \\
\hline 2 & G2 & Batuk-batuk \\
\hline 3 & G3 & Hidung tersumbat/pilek \\
\hline 4 & G4 & Sakit Kepala /Pusing \\
\hline 5 & G5 & Sakit tenggorokan / Susah menelan \\
\hline 6 & G6 & Lesu / Lemas \\
\hline 7 & G7 & Sesak Napas \\
\hline 8 & G8 & Frekuensi napas cepat \\
\hline 9 & G9 & Suara napas kasar \\
\hline 10 & G10 & Nafsu makan berkurang / Susah makan \\
\hline 11 & G11 & Berkurang nya indra pengecap dan bau \\
\hline 12 & G12 & Suara serak \\
\hline 13 & G13 & Gelisah/susah tidur \\
\hline 14 & G14 & Nyeri didada \\
\hline 15 & G15 & Warna merah pada amandel (bengkak) \\
\hline
\end{tabular}

Tabel 3. Tabel Aturan

\begin{tabular}{|c|c|c|}
\hline Rule & IF & THEN \\
\hline R1 & G1,G3,G4,G6,G11,G13 & P1 \\
\hline R2 & G1,G2,G4,G5,G6,G10,G12,G13 & P2 \\
\hline R3 & G1,G2,G4,G6,G10,G12,G13 & P3 \\
\hline R4 & G1,G2,G4,G6,G7,G8,G9,G10,G13 & P4 \\
\hline R5 & G1,G2,G4,G6,G7,G8,G9,G10,G13 & P5 \\
\hline R6 & G1,G2,G4,G6,G7,G8,G9,G10,G13 & P6 \\
\hline R7 & G1,G2,G7,G8,G10,G13,G14 & P7 \\
\hline R8 & G1,G2,G3,G4,G6,G10,G11,G13 & P8 \\
\hline R9 & G1,G2,G4,G6,G10,G13 & P9 \\
\hline
\end{tabular}

Uji Coba Perhitungan Naïve Bayes Classifier

Uji coba perhitungan diterapkan pada yang mengalami gejala Hidung tersumbat/pilek (G3), sakit tenggorokan/susah menelan (G5), sesak napas (G7), frekuensi napas cepat(G8), Berkurangnya indra pengecap dan bau(G11), dan Gelisah/susah tidur (G13). Langkah-langkah perhitungan Naïve Bayes Classifier adalah sebagai berikut :

1. Menentukan nilai $n_{c}$ untuk setiap class

Penyakit ISPA ke-1 : Rhinosinusitis/Sinusitis

$\mathrm{n}=1$

$\mathrm{p}=1 / 9=0.111111111$

G3. $\mathrm{n}_{\mathrm{c}}=1$

G5. $n_{c}=0$

$\mathrm{G} 7 \cdot \mathrm{n}_{\mathrm{c}}=0$

$\mathrm{G} 8 . \mathrm{n}_{\mathrm{c}}=0$

G11. $\mathrm{n}_{\mathrm{c}}=1$

G14. $n_{c}=0$ 
Penyakit ISPA ke-2 : Radang Tenggorokan

$\mathrm{n}=1$

$\mathrm{p}=1 / 9=0.111111111$

$\mathrm{G} 3 . \mathrm{n}_{\mathrm{c}}=0$

$\mathrm{G} 5 . \mathrm{n}_{\mathrm{c}}=1$

$\mathrm{G} 7 \cdot \mathrm{n}_{\mathrm{c}}=0$

$\mathrm{G} 8 . \mathrm{n}_{\mathrm{c}}=0$

$\mathrm{G} 11 . \mathrm{n}_{\mathrm{c}}=0$

G14. $n_{c}=0$

Penyakit ISPA ke-3 : Epiglotis

$\mathrm{n}=1$

$\mathrm{p}=1 / 9=0.111111111$

$\mathrm{G} 3 . \mathrm{n}_{\mathrm{c}}=0$

$\mathrm{G} 5 . \mathrm{n}_{\mathrm{c}}=0$

$\mathrm{G} 7 . \mathrm{n}_{\mathrm{c}}=0$

$\mathrm{G} 8 . \mathrm{n}_{\mathrm{c}}=0$

G11. $n_{\mathrm{c}}=0$

G14. $n_{c}=0$

Dan seterusnya sampai penyakit ISPA ke-9

2. Menghitung nilai $P\left(a_{i} \mid v_{j}\right)$ dan $P\left(v_{j}\right)$

Penyakit ISPA ke-1 :

$$
\begin{aligned}
& P(G 3 \mid P 1)=\frac{1+15+0.111111111}{1+15}=0.111111111 \\
& P(G 5 \mid P 1)=\frac{0+15+0.111111111}{1+15}=0.104166667 \\
& P(G 7 \mid P 1)=\frac{0+15+0.111111111}{1+15}=0.104166667 \\
& P(G 8 \mid P 1)=\frac{0+15+0.111111111}{1+15}=0.104166667 \\
& P(G 11 \mid P 1)=\frac{1+15+0.111111111}{1+15}=0.111111111 \\
& P(G 14 \mid P 1)=\frac{0+15+0.111111111}{1+15}=0.104166667 \\
& P(P 1)=\frac{1}{9}=0.111111111
\end{aligned}
$$

Penyakit ISPA ke-2 :

$$
\begin{aligned}
& P(G 3 \mid P 2)=\frac{0+15+0.111111111}{1+15}=0.104166667 \\
& P(G 5 \mid P 2)=\frac{1+15+0.111111111}{1+15}=0.111111111
\end{aligned}
$$




$$
\begin{aligned}
& P(G 7 \mid P 2)=\frac{0+15+0.11111111}{1+15}=0.104166667 \\
& P(G 8 \mid P 2)=\frac{0+15+0.111111111}{1+15}=0.104166667 \\
& P(G 11 \mid P 2)=\frac{0+15+0.111111111}{1+15}=0.104166667 \\
& P(G 14 \mid P 2)=\frac{0+15+0.111111111}{1+15}=0.104166667 \\
& P(P 2)=\frac{1}{9}=0.111111111
\end{aligned}
$$

Penyakit ISPA ke-3 :

$$
\begin{aligned}
& P(G 3 \mid P 3)=\frac{0+15+0.111111111}{1+15}=0.104166667 \\
& P(G 5 \mid P 3)=\frac{0+15+0.111111111}{1+15}=0.104166667 \\
& P(G 7 \mid P 3)=\frac{0+15+0.11111111}{1+15}=0.104166667 \\
& P(G 8 \mid P 3)=\frac{0+15+0.11111111}{1+15}=0.104166667 \\
& P(G 11 \mid P 3)=\frac{0+15+0.111111111}{1+15}=0.104166667 \\
& P(G 14 \mid P 3)=\frac{0+15+0.111111111}{1+15}=0.104166667 \\
& P(P 3)=\frac{1}{9}=0.111111111
\end{aligned}
$$

Dan seterusnya sampai penyakit ISPA ke-9

3. Menghitung nilai $P\left(v_{j}\right) \times P\left(a_{i} \mid v_{j}\right)$ untuk setiap v.

Penyakit ISPA ke-1 : $\quad \mathrm{P}(\mathrm{P} 1)$ x $[\mathrm{P}(\mathrm{G} 3 \mid \mathrm{P} 1)$ x $\mathrm{P}(\mathrm{G} 5 \mid \mathrm{P} 1)$ x $\mathrm{P}(\mathrm{G} 7 \mid \mathrm{P} 1)$ x $\mathrm{P}(\mathrm{G} 8 \mid \mathrm{P} 1)$ x $\mathrm{P}(\mathrm{G} 11 \mid \mathrm{P} 1) \times \mathrm{P}(\mathrm{G} 14 \mid \mathrm{P} 1)]$ $=0,111111111 \times 0,104166667 \times 0,104166667 \times 0,104166667 \times$ $0,111111111 \times 0,104166667$ $=1,4535 \mathrm{e}-6$

Penyakit ISPA ke-2: $\quad \mathrm{P}(\mathrm{P} 2)$ x $[\mathrm{P}(\mathrm{G} 3 \mid \mathrm{P} 2)$ x $\mathrm{P}(\mathrm{G} 5 \mid \mathrm{P} 2)$ x $\mathrm{P}(\mathrm{G} 7 \mid \mathrm{P} 2)$ x $\mathrm{P}(\mathrm{G} 8 \mid \mathrm{P} 2) \times$ $\mathrm{P}(\mathrm{G} 11 \mid \mathrm{P} 2) \times \mathrm{P}(\mathrm{G} 14 \mid \mathrm{P} 2)]$ $=0,104166667 \times 0,111111111 \times 0,104166667 \times 0,104166667 \times$ $0,104166667 \times 0,104166667$ $=1,362703 \mathrm{e}-6$ 
Penyakit ISPA ke-3 : $\quad \mathrm{P}(\mathrm{P} 3)$ x $[\mathrm{P}(\mathrm{G} 3 \mid \mathrm{P} 3)$ x $\mathrm{P}(\mathrm{G} 5 \mid \mathrm{P} 3)$ x $\mathrm{P}(\mathrm{G} 7 \mid \mathrm{P} 3)$ x $\mathrm{P}(\mathrm{G} 8 \mid \mathrm{P} 3)$ x $\mathrm{P}(\mathrm{G} 11 \mid \mathrm{P} 3) \times \mathrm{P}(\mathrm{G} 14 \mid \mathrm{P} 3)]$ $=0,104166667 \times 0,104166667 \times 0,104166667 \times 0,104166667 \times$ $0,104166667 \times 0,104166667$ $=1,277534 \mathrm{e}-6$

Dan seterusnya sampai penyakit ISPA ke-9

4. Menentukan hasil klasifikasi yaitu v yang memiliki nilai perkalian terbesar.

\begin{tabular}{|l|l|}
\hline Penyakit & Nilai v \\
\hline Rhinosinusitis / Sinusistis & $1,4535 \mathrm{e}-6$ \\
\hline Tonsilitis, Faringitis, Laringitis (Radang Tenggorokan) & $1,362703 \mathrm{e}-6$ \\
\hline Epiglotis & $1,277534 \mathrm{e}-6$ \\
\hline Bronkitis & $1,45355 \mathrm{e}-6$ \\
\hline Bronkiolitis & $1,45355 \mathrm{e}-6$ \\
\hline Pneumonia & $1,45355 \mathrm{e}-6$ \\
\hline Pleuritis & $1,550454 \mathrm{e}-6$ \\
\hline Commond Cold & $1,45355 \mathrm{e}-6$ \\
\hline ILI ( Influenza Like Illness) & $1,277534 \mathrm{e}-6$ \\
\hline
\end{tabular}

Nilai v terbesar adalah 1,550454e-6. Dapat disimpulkan bahwa pengguna menderita penyakit Pleuritis.

\section{Design}

Pada tahap ini merupakan tahapan perancangan perangkat lunak, meliputi perancangan sistem, database dan antarmuka untuk tampilan aplikasi. Perancangan sistem meliputi perancangan pemodelan Unified Modeling Language (UML) yaitu dengan Use Case dapat dilihat pada Gambar 2.1 Perancangan database menggunakan Entity Relational Diagram (ERD) dapat dilihat pada gambar 2.2.

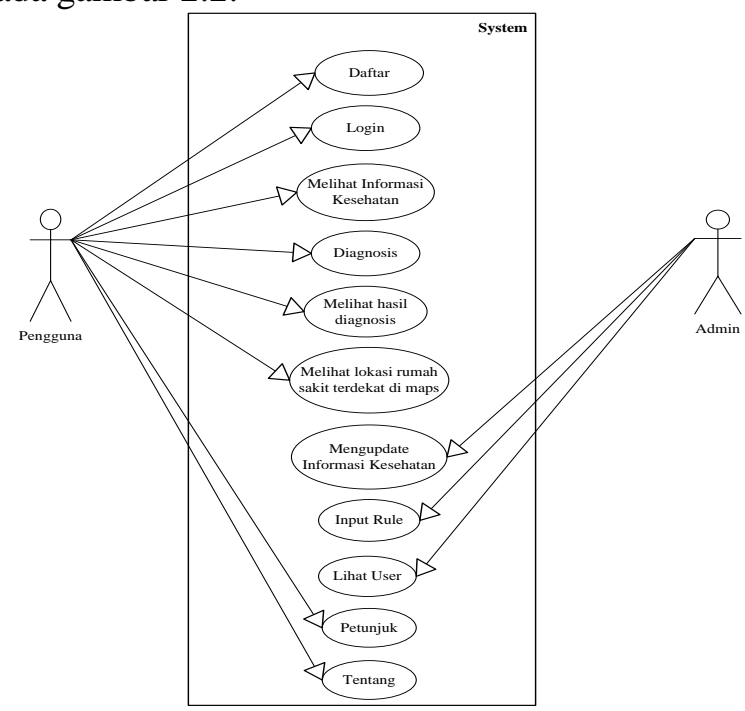

Gambar 2.2 Use Case 


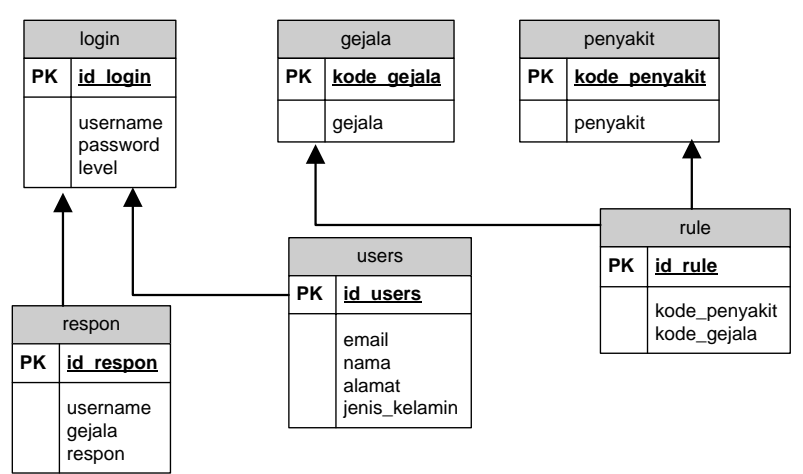

Gambar 2.3 Entity Relational Diagram

\section{Code}

Pada tahap ini merupakan tahapan penulisan kode program. Penulisan kode program menggunakan bahasa pemrograman Java dengan editor Android Studio.

4. Test

Pada tahap ini, dilakukan pengujian terhadap aplikasi yang telah dibuat untuk memastikan bahwa kinerja dari aplikasi sudah benar sesuai yang diharapkan.

\section{Hasil dan Pembahasan}

Penelitian ini menghasilkan piranti lunak berupa aplikasi yaitu Sistem Pakar Diagnosis Penyakit ISPA Berbasis android dengan Speech Recognition Menggunakan Metode Naive Bayes Classifier yang mampu mendiagnosis penyakit ISPA yang bisa menggunakan suara sehingga lebih interaktif dan mampu memberikan solusi beserta lokasi rumah sakit terdekat yang disarankan. Aplikasi ini dirancang dengan menggunakan bahasa pemrograman Java dan editor Android studio.

Adapun antar muka untuk aplikasi Sistem pakar Diagnosis Penyakit ISPA Berbasis android dengan Speech Recognition Menggunakan Metode Naive Bayes Classifier dapat dilihat pada Gambar 3.1 berikut.

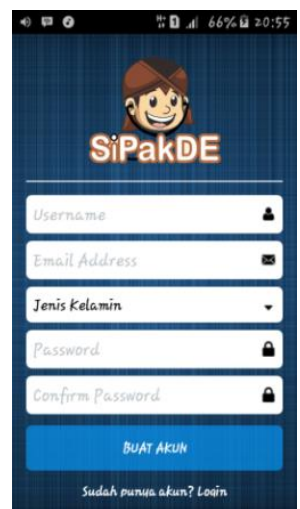

(a)

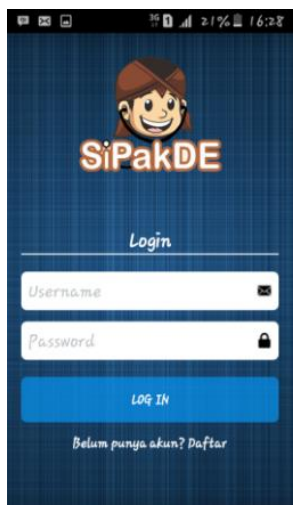

(b)

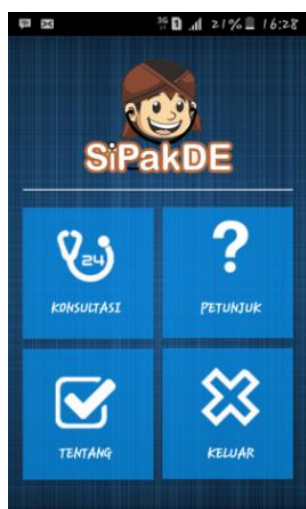

(c) 


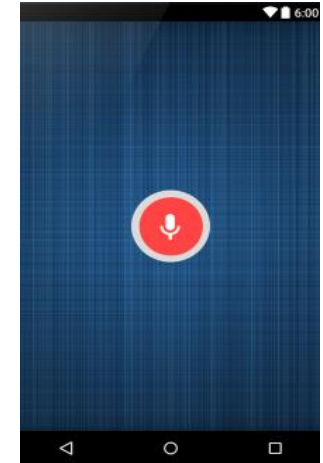

(d)

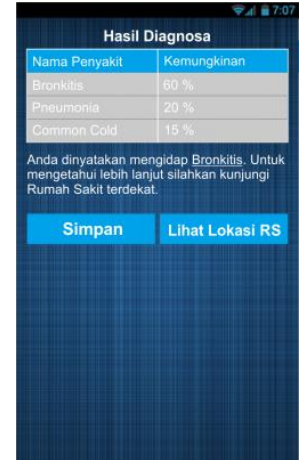

(e)

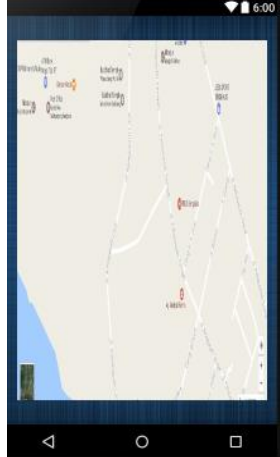

(f)

Gambar 3.1 a. Antarmuka Daftar Akun, b. Antarmuka Login, c. Antarmuka Menu Utama, d. Form Konsultasi, e. hasil diagnose,f. hasil map rumah sakit terdekat jika positif terjangkit ISPA

Adapun proses sistem yang terjadi pada saat user melakukan diagnosa penyakit ISPA menggunakan suara sampai mendapatkan hasil diagnosis dapat dilihat sebagai berikut :

1. Tahap proses konsultasi menggunakan library speech to text dan menggunakan fungsi speech to text yang telah tersedia dimana suara yang di inputkan akan di konversi kan menjadi sebuah text untuk lebih jelas bisa dilihat di Gambar4.

private void startSpeechToText ()\{

Intent intent $=$ new Intent $\left(\operatorname{RecognizerIntent.ACTION\_ RECOGNIZE\_ SPEECH}\right)$; intent.putExtra(RecognizerIntent.EXTRA_LANGUAGE, Locale.getDefault()); intent.putExtra(RecognizerIntent.EXTRA_LANGUAGE_MODEL, RecognizerIntent.LANGUAGE_MODEL_FREE_FORM); intent.putExtra(RecognizerIntent.EXTRA_PROMPT, "Katakan Sesuatu..."); try \{

startActivityForResult(intent, SPEECH_RECOGNITION_CODE); \} catch (ActivityNotFoundException a) \{

Toast.makeText(getApplicationContext(),

"Sorry! Speech recognition is not supported in this device.", Toast.LENGTH_SHORT).show();

\}

\}

@Override

protected void onActivityResult(int requestCode, int resultCode, Intent data) \{ super.onActivityResult(requestCode, resultCode, data); switch (requestCode) \{ case SPEECH_RECOGNITION_CODE: if (resultCode $==\boldsymbol{R} \boldsymbol{E S U L T} \boldsymbol{O} \boldsymbol{O K} \& \&$ null != data) \{

ArrayList $<$ String $>$ result $=$ data .getStringArrayListExtra(RecognizerIntent.EXTRA_RESULTS);

String text $=$ result.get $(0)$

txtOutput.setText(text);

\} startRespon();

break;

case SPEECH_1: \{

if (resultCode $==\boldsymbol{R} \boldsymbol{E S U L T} \boldsymbol{T} \boldsymbol{O K} \& \&$ null != data) \{ 


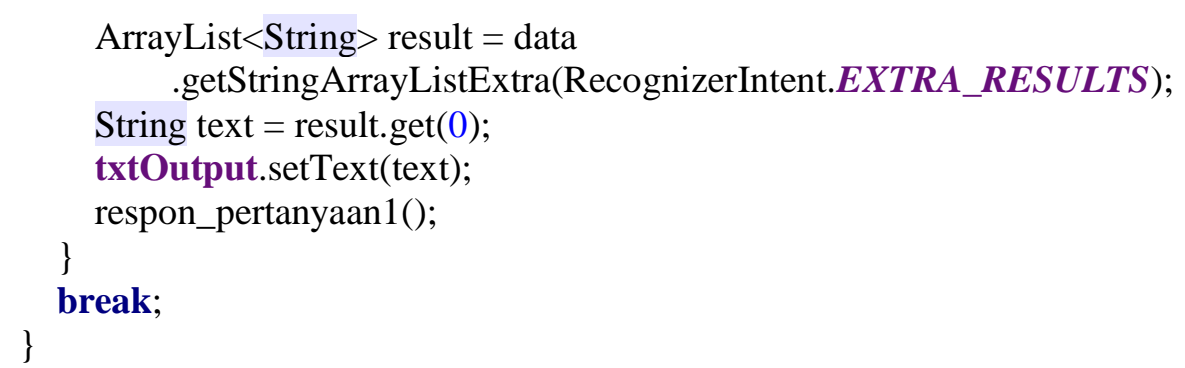

Gambar 3.2 fungsi speech to text merubah suara menjadi text.

2. Untuk proses diagnosa menggunakan metode Naive Bayes Classifier berikut beberapa potongan syntak dalam Gambar 3.3

$<$ ?php

include 'config.php';

\$username $=$ \$_POST['username'];

\$respon $=$ \$_POST['respon'];

\$tanggal = date $\left(' Y-m-d^{\prime}\right)$;

if $(\$ r e s p o n==' y a$ or $\$$ respon=='iya' $)\{$

\$nilai='1';

\}

if $($ respon=='tidak' or $\$$ respon=='enggak' $)\{$

\$nilai='0';

\}

\$gejala = \$_POST['gejala'];

\$mysql_qry = "INSERT INTO respon

(id_respon,username, gejala,respon,tanggal)VALUES(",'\$username','\$gejala','\$nilai','\$t anggal')";

if $($ \$conn->query $($ mysql_qry $)===$ TRUE $)\{$

$\$ \mathrm{n}=1$;

\$default $=0.111111111$

\$bagi $=16$;

$\$$ sql $=$ "SELECT $*$ FROM respon WHERE username='\$username' AND respon $!={ }^{\prime} 0^{\prime}$

AND tanggal='\$tanggal' ORDER BY id_respon ASC ";

\$rule $=$ "SELECT $*$ FROM rule";

\$res $=$ mysqli_query $(\$ c o n n, \$ r u l e)$;

\$sqlres = mysqli_query $($ conn,$\$ s q 1)$;

\$hasil=1;

$$
\text { while }(\$ o=\text { mysqli_fetch_array }(\$ \text { sqlres }))\{
$$

if $\left(\$ o\left[{ }^{\prime}\right.\right.$ gejala'] =='G1' OR \$o['gejala'] =='G2' OR

$\$ o[$ 'gejala']=='G3' OR \$o['gejala']=='G4' OR \$o['gejala']=='G6' OR \$o['gejala']=='G11'

)

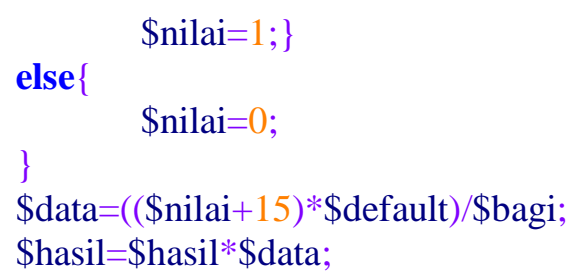




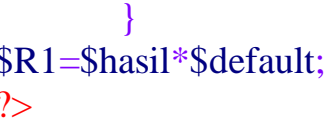

Gambar 3.3 Algoritma Naive Bayes Classifier.

3. Metode menentukan rumah sakit terdekat lihat Gambar 4.3

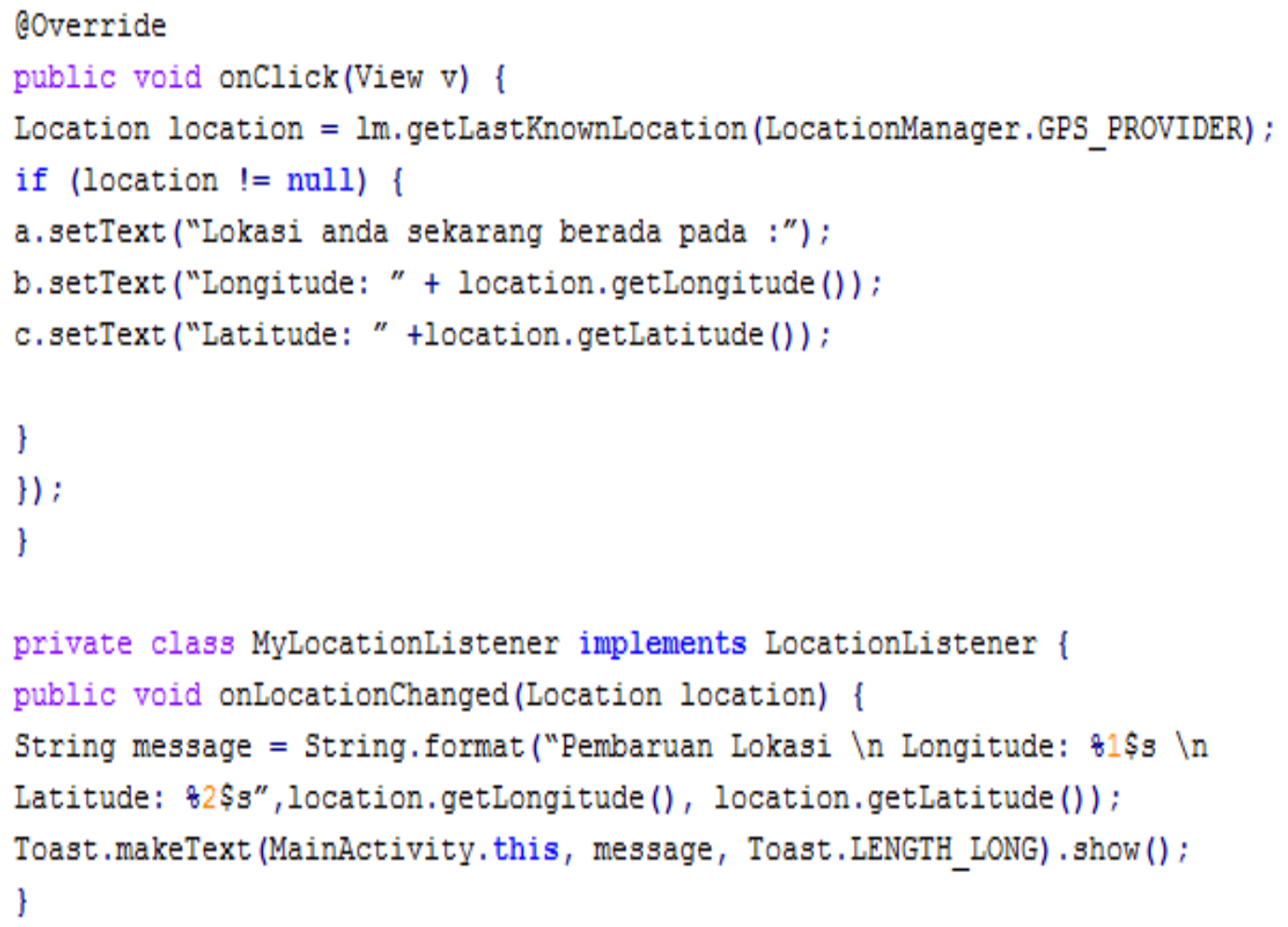

\section{Kesimpulan}

Berdasarkan hasil dan pengujian terhadap penggunaan aplikasi aplikasi Sistem pakar Diagnosis Penyakit ISPA Berbasis android dengan Speech Recognition Menggunakan Metode Naive Bayes Classifier mampu mengklaster jawaban dari user berdasarkan rule yang dibuat sehingga mendapatkan hasil diagnosa.

Sistem pakar ini dapat berjalan dengan baik pada perangkat android. Dari segi tampilan aplikasi, aplikasi ini fleksibel sehingga mampu menyesuaikan bentuk tampilan pada perangkat tersebut.

\section{Daftar Pustaka}

[1] Ahmad, R., Rizal, R.I., dan Ike, P.W., 2015, Pengembangan Sistem Pakar Untuk Diagnosis Penyakit Hepatitis Berbasis Web Menggunakan Metode Certainty Factor, Jurnal Teknologi dan Sistem Komputer, Vol.3, No.1.

[2] Ardian, B.P., 2014, Sistem Pakar Untuk Mendiagnosa Penyakit Infeksi Saluran Pernafasan Akut Berbasis Web, Dokumen Karya Ilmiah Universitas Dian Nuswantoro Semarang.

[3] Reddy B.R. dan Mahender, E., 2013, Speech to Text Conversion using Android Platform, International Journal of Engineering Research and Applications (IJERA), Vol. 3, Issue 1.

[4] Deni, W., 2013, Sistem Pakar Diagnosa ISPA Berbasis Web dengan Metode Forward Chaining, Jurnal TI-STMIK Atma Luhur Pangkal pinang. 
[5] Hendra, E., 2016, Sistem Pakar Diagnosis Penyakit Infeksi Saluran Pernapasan Akut Pada Anak Menggunakan Metode Naive Bayes Classifier, Seminar Nasional Teknologi Informasi, Bisnis, dan Desain 2016.

[6] Kartika, I.S., 2016, Aplikasi Location Based Service Layanan Kesehatan Kota Magelang Berbasis Android, INFOKAM, Vol.12, No.1.

[7] Kementerian Kesehatan RI, 2016, "Profil Kesehatan Indonesia Tahun 2015".

[8] Pressman, R.S., 2011, Software Engineering a Practitioner's Approach. $5^{\text {th }}$ Edition. Mc Graw Hill. New York - USA.

[9] Preeti, S., dan Parneet, K., 2013, Automatic Speech Recognition: A Review, International Journal of Engineering Trends and Technology, Volume 4, Issue2- 2013.

[10] Shunfu, H. dan Ting, D., 2013, Online Map Application Development Using Google Maps API, SQL Database, and ASP.NET, ICT Journal, Vol.3, No.3.

[11] WHO, 2007, "Pencegahan dan Pengendalian infeksi saluran pernapasan akut (ISPA) yang cenderung menjadi epidermi dan pandemic di fasilitas pelayanan kesehatan”. 